\title{
17: 77603052-77608635
}

National Cancer Institute

\section{Source}

National Cancer Institute. 17: 77603052-77608635. NCI Thesaurus. Code C42417.

Physical location of GPS1_Gene 